\title{
İşsizlikte Histeri Etkisi: Türkiye Örneği
}

\author{
Hysteresis Effect in Unemployment: Turkey Case
}

\author{
Taha Bahadır SARAÇ
}

\begin{abstract}
ÖZET
Türkiye'de (2005:01-2013:07) döneminde işsizlikte histeri etkisi ile işsizlikte histeri etkisinin araştırılmasında işsizlik oranları serisinin kullanılıp kullanılamayacağının incelendiği bu çalışmada, doğrusal birim kök testi sonuçlarına göre işsizlik ve işgücüne katılma oranı serilerinin durağan olduğu, doğrusal olmayan birim kök testi sonucuna göre sadece işsizlik oranları serisinin bir rejimde durağan olduğu sonucuna ulaşılmıştır. Bu sonuçlar ışığında, Türkiye'de işsizlikte histeri etkisinin sadece bir rejimde geçerli olduğu ve işsizlikte histeri etkisini yansıtması anlamında işsizlik oranları değişkeninin kullanılabileceği ortaya konulmuş olmaktadır.
\end{abstract}

Anahtar Kelimeler: İşsizlik, histeri etkisi, doğrusal olmayan birim kök testi

\section{GiRiş}

1970'li yılların ortalarından itibaren Avrupa ülkelerinde gözlenen yüksek ve kalıc işsizlik oranları karşısında, Phelps $(1967,1968)$ ve Friedman (1968)'nın doğal oran hipotezi yaklaşımları yeniden gözden geçirilmeye başlanmış ve sırasıyla histeri ve yapısalcı yaklaşımların ortaya çıkmasına neden olmuştur. Doğal işsizlik oranı hipotezinde, ekonomide meydana gelen şoklar karşısında işsizlik oranlarının doğal seviyesinin değişmeyeceği, diğer bir deyişle ekonomide geçici şokların, işsizliğin doğal oranında geçici bir etkiye neden olacağı ileri sürülmüştür (Papell vd., 2000: 310). Buna karşılık, Blanchard ve Summers (1986, 1987), Cross (1987), Barro (1988) ve Layard vd. (1991) tarafından geliştirilen işsizlikte histeri yaklaşımında, cari dönem işsizlik oranlarının bir önceki dönem işsizlik oranlarına bağlı olduğu ve ekonomide meydana gelen şokların, işsizlik oranlarında kalıcı bir etki meydana getirdiği savunulmuştur. Diğer bir deyişle, işsizlik oranlarının ortalamaya dönme eğilimi taşımadığı kabul edilmiştir. İşsizlik oranlarında görülen söz konusu bu kalıcılığın ise üç görüş ile açıklandığı görülmektedir: Bu görüşlerden fiziki sermaye görüşüne göre (Sneessens, 1983; Sneessens ve Dreze, 1986; Burda, 1988) istihdam azalışlarına bağlı olarak oluşan fiziki sermaye stokundaki azalma, bir sonraki dönem

\section{ABSTRACT}

In this study which examines the hysteresis effect between January 2005 and July 2013 in Turkey and whether the unemployment series rates can be used in studying hysteresis effect or not, it has been concluded that the unemployment series and labor force participation rate series are stable according to the results of linear unit root test and the unemployment series are stable only at one regime according to the result of nonlinear unit root test. In the light of these results, it has been suggested that the hysteresis effect at unemployment in Turkey is valid only in one regime and the unemployment rates variable can be used to reflect hysteresis effect at unemployment.

Keywords: Unemployment, hysteresis effect, nonlinear unit root test

emek talebini olumsuz etkilemekte ve böylelikle işsizlik süresi uzamaktadır. Bu görüşe destek olması anlamında, o zamanki ismiyle Avrupa Ekonomik Topluluğu'nda işsizlik oranlarının yükselmesine karşın 1975, 1979 ve 1983 yılları ile karşılaştırıldığında, kapasite kullanım oranlarının artmaması ve bu nedenle varolan kapasite kullanım seviyesinin, mevcut işgücünü istihdam edecek yeterlilikte olmaması örnek olarak gösterilmektedir. Fakat Blanchard ve Summers (1986) bu örneği kuşkuyla karşılaşmışlar ve tarihsel süreç içerisinde fiziki sermayede meydana gelen azalışların, işsizlik oranları üzerinde uzun dönem olumsuz etkileri olduğunun, tarihsel deneyim ile çok fazla desteklenemeyeceğini ileri sürmüşlerdir. İkinci görüş olan beşeri sermeye görüşünde (Phelps, 1972; Hargraves, 1980; Layard vd.,1991; Pissarides, 1992) ise uzun süre işsiz kalan kişilerin, işsiz kaldıkları sürece çalışarak artırabilecekleri yeteneklerinin azalabileceğine ve bu nedenle yeniden iş bulma ümitlerinin kaybolabileceğine ve işsizlik süresinin uzayabileceğine değinilmektedir. Son olarak içerdekiler-dışarıdakiler yaklaşımında, Blanchard ve Summers (1986, 1987), ücretlerin içerdekiler (çalışanlar) ile firmalar arasında belirlendiği ve bu süreçte dışarıdakilerin (çalışmayanların) herhangi bir etkisi olmadığını kabul etmişlerdir. Bu anlamda, Blanchard ve Summers $(1986,1987)$ sadece mev- 
cut işlerini devam ettirme çabası içerisinde olan içerdekilerin, ekonomik şokların varlığı durumunda kendi işlerinin devamını sağlayacak bir ücret seviyesi belirleyeceğini ve bu nedenle de ücretlerin düşmeyeceğini ve işsizlik oranlarının azalmayacağını düşünmüşlerdir. İçerdekiler-dışarıdakiler yaklaşımı çerçevesinde Lindbeck ve Snower $(1988,2001)$ ise firmalar açısından iş dönüştürme maliyetlerinin (işe alma, işe hazırlama, işten çıkarma) yeni iş̧̧i kiralamanın maliyetinden yüksek olması nedeniyle, firmaların yeni işçi çalıştırmak istemeyeceklerini ve böylelikle işsizlik süresinin uzayabileceğini iddia etmişlerdir. İşsizlik oranlarındaki histeri etkisini açıklamaya çalışan bu yaklaşımların aksine Phelps (1994) tarafından geliştirilen yapısalcı yaklaşımda; ekonomide meydana gelen yapısal değişiklikler karşısında doğal işsizlik oranlarının değişebileceği fakat işsizlik oranlarının yapısal kırılmalara rağmen ortalamaya dönme eğilimi taşıyabileceği, diğer bir deyişle doğal işsizlik oranı hipotezinden farklı olarak, doğal işsizlik oranlarının değişebileceği savunulmuştur.

Özet olarak anlatılmaya çalışılan söz konusu bu görüşlerin geçerliliğinin zaman içerisinde bir çok çalışmada sınandığı gözlenmektedir. Bu çalışmalar incelendiğinde genellikle işsizlikte histeri etkisinin araştırılmasında sadece işsizlik oranları serisinin ve ekonometrik yöntem olarak ise birim kök testlerinin kullanıldığı görülmektedir. Söz konusu birim kök testlerinde ise sadece işsizlik oranlarının yer alması bir çok çalışmada (Murphy ve Topel, 1997; Gustavvson ve Österholm, 2006, 2007; Madsen vd., 2008; Andersen, 2010) eleştirilmiştir. Bu çalışmalardan Murphy ve Topel (1997)'de Amerika Birleşik Devletleri'ndeki düşük nitelikli işgücü içerisinde önemli ölçüde cesareti kırılmış işçi etkisinin olması nedeniyle, işsizlik oranlarının zaman içerisinde işgücü piyasası hakkında daha az bilgi sunduğu belirtilirken; Gustavvson ve Österholm $(2006,2007)$ çalışmalarında, işsizlik oranlarının, işsiz sayısındaki değişmeleri tek başına yansıtamayacağını ifade etmişlerdir. Özellikle Gustavvson ve Österholm (2006)'daki çalışmalarında Camero ve Tamarit'in (2004)'deki 19 OECD ülkesindeki işsizlikte histeri etkisini inceledikleri çalışmalarını eleştirdikleri ve Avusturalya, Kanada ve Amerika Birleşik Devletleri'nde işgücüne katılma oranlarının birim kök içerip içermediğini araştırdıkları çalışmalarında, işgücüne katılma oranlarının birim kök içerdiği durumlarda işsizliği yansıtması anlamında işsizlik oranları serisinin kullanmasının yanıltıcı olabileceğini ortaya koymaya çalışmışlardır. Gustavvson ve Österholm (2006) bu tespitlerini ise işgücüne katılma oranlarının durağan bir özellik taşıdığı durumlarda, işsizlik oranlarının uzun dönem istihdam oranlarındaki değişimleri yansıtabileceği düşüncesine dayandırmışlardır. Işgücüne katılma oranlarının kullanıldığı diğer bir çalışmada Madsen $v d$., (2008), doğal işsizlik oranı hipotezi altında, işgücüne katılma oranlarının yükselmesi durumunda işsizlik oranlarının başlangıçta artacağı fakat bu durumun ücretlerde aşağı yönlü bir baskı oluşturması nedeniyle istihdam oranlarının yükseleceği ve işsizlik oranının, doğal seviyesinde dengeye geleceğine değinerek, işgücüne katılma oranlarının birim kök içermemesi halinde işsizlik oranlarının işsizlik için faydalı bir gösterge olabileceğini iddia etmişlerdir. Bu açıklamalar doğrultusunda hazırlanan bu çalışmada ise, Türkiye ekonomisindeki işsizlik oranlarındaki histeri etkisinin varlığı ile işsizlikte histeri etkisini yansıtması anlamında işsizlik oranlarının yeterliliğinin doğrusal ve doğrusal olmayan birim kök testleri kullanılarak incelenmesi amaçlanmıştır. Bu nedenle çalışmada genel işşizlik oranı dışında, işgücüne katılma oranı değişkeni de ekonometrik analize dahil edilmiştir. Bu bağlamda, beş bölüm şeklinde hazırlanan çalışmada, ikinci bölümde konu ile ilgili literatür özetine yer verilmiş, üçüncü bölümde çalışmada benimsenen ekonometrik yöntem açıklanmış ve ekonometrik yöntemden elde edilen bulguların yer aldığı dördüncü bölümün ardından ise sonuç bölümü ile çalışma tamamlanmıştır. 


\section{LITERATÜR ÖZETI}

İşsizlikte histeri etkisini konu alan çalışmalara ait literatür Tablo 1'de özetlenmiştir.

Tablo 1: Literatür Özeti

\begin{tabular}{|c|c|c|c|}
\hline Yazar(lar) & $\begin{array}{l}\text { Dönem ve } \\
\text { Veri Seti }\end{array}$ & Yöntem(ler) & Sonuç(lar) \\
\hline $\begin{array}{l}\text { Jaeger ve Par- } \\
\text { kinson } \\
\text { (1990) }\end{array}$ & $\begin{array}{l}(1954: 1-1989: 1) \\
\text { Genel İşsizlik Oranı }\end{array}$ & Gözlenmeyen Bileşenler Yöntemi & $\begin{array}{l}\text { Almanya'da işsizlikte histeri etkisinin geçerli olduğu buna } \\
\text { karşılık ABD'de ise geçerli olmadığını tespit etmişlerdir. }\end{array}$ \\
\hline $\begin{array}{l}\text { Neudorfer ve vd. } \\
(1990)\end{array}$ & $\begin{array}{l}\text { (1966-1986) } \\
\text { Genel İşsizlik Oranları }\end{array}$ & $\begin{array}{l}\text { Birim Kök Testi ve Ücret-Fiyat } \\
\text { Modeli }\end{array}$ & $\begin{array}{l}\text { Avusturalya'da işsizlikte histeri etkisinin geçerli olduğu } \\
\text { belirlemiştir. }\end{array}$ \\
\hline Røed (1996) & $\begin{array}{l}\text { (1970:1-1994:4) } \\
\text { Genel İşsizlik Oranları }\end{array}$ & Birim Kök Testi & $\begin{array}{l}\text { İşsizlikte histeri etkisinin Avusturalya ve Kanada'da güçlü } \\
\text { olduğu, Japonya ve çoğu Avrupa ülkesinde zayıf olduğu ve } \\
\text { ABD'de ise söz konusu bu etkinin geçerli olmadığı sonucuna } \\
\text { ulaşmıştır. }\end{array}$ \\
\hline Küçükkale (2001) & $\begin{array}{l}(1950-1995) \\
\text { Genel İşsizlik Oranları }\end{array}$ & Kalman Filtresi & $\begin{array}{l}\text { Doğal işsizlik oranı hipotezinin zayıf da olsa geçerli olduğunu } \\
\text { belirlemiştir. }\end{array}$ \\
\hline $\begin{array}{l}\text { Gil-Alana } \\
(2002)\end{array}$ & $\begin{array}{l}\text { (1966:1-2002:2) } \\
\text { Genel İşsizlik Oranları }\end{array}$ & Uzun Hafıza Modelleri & Kanada'da ilgi dönemde işsizlikte histeri etkisini belirlemiştir. \\
\hline $\begin{array}{l}\text { Chang ve vd. } \\
(2005)\end{array}$ & $\begin{array}{l}(1961-1999) \\
\text { Genel İşsizlik Oranları }\end{array}$ & Panel Birim Kök Testi & $\begin{array}{l}\text { Belçika ve Hollanda dışında diğer Avrupa ülkelerinde işsizlikte } \\
\text { histeri etkisinin geçerli olduğunu tespit etmişlerdir. }\end{array}$ \\
\hline $\begin{array}{l}\text { Mikhail ve vd. } \\
\text { (2006) }\end{array}$ & $\begin{array}{l}\text { (1976:1-1999:4) } \\
\text { Genel İşsizlik Oranları }\end{array}$ & Uzun Hafıza Modelleri & $\begin{array}{l}\text { Kanada'da kısa ve orta dönemde işsizlik oranlarında kalıcılık } \\
\text { belirlemişlerdir. }\end{array}$ \\
\hline $\begin{array}{l}\text { Camero vd. } \\
(2008)\end{array}$ & $\begin{array}{l}(1991: 1-2003: 11) \\
\text { Genel İşsizlik Oranları }\end{array}$ & $\begin{array}{l}\text { Yapısal Kırılmalı Panel Birim Kök } \\
\text { Testi }\end{array}$ & $\begin{array}{l}\text { Geçiş ekonomilerinde işsizlik oranlarında histeri etkisinin } \\
\text { geçerli olmadığını ortaya koymuşlardır. }\end{array}$ \\
\hline $\begin{array}{l}\text { Romero-Ávila } \\
\text { ve Usabiaga } \\
\text { (2008) }\end{array}$ & $\begin{array}{l}\text { Farklı Dönemler } \\
\text { Bölgesel İşsizlik } \\
\text { Oranları }\end{array}$ & $\begin{array}{l}\text { Yapısal Kırılmalı Panel Birim Kök } \\
\text { Testi }\end{array}$ & $\begin{array}{l}\text { İspanya'da işsizlikte güçlü bir histeri etkisi olduğunu tespit } \\
\text { etmişlerdir. }\end{array}$ \\
\hline Yılancı (2008) & $\begin{array}{l}\text { Farklı Dönemler } \\
\text { Genel İşsizlik Oranları }\end{array}$ & $\begin{array}{l}\text { Doğrusal ve Doğrusal Olmayan } \\
\text { Birim Kök Testleri }\end{array}$ & $\begin{array}{l}\text { Avusturalya, Kanada, Finlandiya, Japonya, Lüksemburg, Nor- } \\
\text { veç, Slovakya ve Türkiye'de işsizlikte histeri etkisinin geçerli } \\
\text { olduğunu belirlemiştir. }\end{array}$ \\
\hline $\begin{array}{l}\text { Barışık ve Çevik } \\
(2008)\end{array}$ & $\begin{array}{l}(1923-2006) \\
\text { Genel İşsizlik Oranları }\end{array}$ & $\begin{array}{l}\text { Yapısal Kırılma, Yapısal Kırılmalı } \\
\text { Birim Kök ve Yarı Parametrik Güçlü } \\
\text { Hafıza Testleri }\end{array}$ & Histeri etkisini ortaya koymuşlardır. \\
\hline $\begin{array}{l}\text { Barışık ve Çevik } \\
\text { (2008) }\end{array}$ & $\begin{array}{l}(1988: 1-2007: 2) \\
\text { Sektörel İşsizlik } \\
\text { Oranları }\end{array}$ & $\begin{array}{l}\text { Yapısal Kırılma, Yapısal Kırılmalı } \\
\text { Birim Kök ve Yarı Parametrik Güçlü } \\
\text { Hafıza Testleri }\end{array}$ & $\begin{array}{l}\text { İmalat sanayi ve mali kurumlar sektöründe histeri etkisi olduğu } \\
\text { sonucuna ulaşmışlardır. Bu sonucun gerekçesi olarak da imalat } \\
\text { sektöründe teknoloji yoğun malların üretilmesi ve bankacılık } \\
\text { sektöründeki şubesiz bankacılığın devam etmesinin etkili } \\
\text { olduğunu ileri sürmüşlerdir. }\end{array}$ \\
\hline Yılancı (2009) & $\begin{array}{l}(1923-2007) \\
\text { Genel İşsizlik Oranları }\end{array}$ & $\begin{array}{l}\text { Yapısal Kırılmaları Dikkate Alan } \\
\text { Birim Kök Testleri }\end{array}$ & $\begin{array}{l}\text { Zaman boyunca meydana gelen şokların işsizliğin doğal } \\
\text { oranında değişmelere neden olduğunu ve işsizlik oranlarını } \\
\text { kalıcı olarak etkilediğini tespit etmiştir. }\end{array}$ \\
\hline Lee (2010) & $\begin{array}{l}\text { Farklı Dönemler } \\
\text { Genel İşsizlik Oranları }\end{array}$ & $\begin{array}{l}\text { Doğrusal Olmayan Panel Birim } \\
\text { Kök Testi }\end{array}$ & $\begin{array}{l}23 \text { OECD ülkesinde işsizlikte histeri etkisi olmadığı sonucuna } \\
\text { ulaşmıştır. }\end{array}$ \\
\hline $\begin{array}{l}\text { Fosten ve } \\
\text { Ghoshray } \\
\text { (2011) }\end{array}$ & $\begin{array}{l}(1855-2008) \\
\text { Genel İşsizlik Oranları }\end{array}$ & Rejim Değişim Modeli & $\begin{array}{l}\text { Kanada, Avusturalya ve İsveç hariç İngiltere, ABD ve } \\
\text { Danimarka'da belirli dönemlerde işsizlikte histeri etkisinin } \\
\text { olduğunu belirlemişlerdir. }\end{array}$ \\
\hline $\begin{array}{l}\text { Chang ve Lee } \\
(2011)\end{array}$ & $\begin{array}{l}\text { (1992:01-2008:09) } \\
\text { Genel İşsizlik Oranları }\end{array}$ & Doğrusal Olmayan Birim Kök Testi & $\begin{array}{l}\text { Fransa, Almanya ve İtalya'da işsizlikilte histeri etkisinin geçerli } \\
\text { olduğunu tespit etmişlerdir. }\end{array}$ \\
\hline $\begin{array}{l}\text { Cuestas vd. } \\
(2011)\end{array}$ & $\begin{array}{l}\text { (1998:01-2007:12) } \\
\text { Genel İşsizlik Oranları }\end{array}$ & Kesirli Eşbütünleşme Analizi & $\begin{array}{l}\text { Macaristan ve Slovakya'da işsizlik oranlarında zayıf bir histeri } \\
\text { etkisi olduğu buna karşlık Çek Cumhuriyeti, Slovakya ve } \\
\text { Baltık ülkelerinde söz konusu bu etkinin güçlü olduğunu } \\
\text { belirlemişlerdir. }\end{array}$ \\
\hline $\begin{array}{l}\text { Güloğlu ve İspir } \\
\text { (2011) }\end{array}$ & $\begin{array}{l}(1988-2008) \\
\text { Sektörel İşsizlik } \\
\text { Oranları }\end{array}$ & $\begin{array}{l}\text { Yapısal Kırılmalı Panel Birim Kök } \\
\text { Testi }\end{array}$ & $\begin{array}{l}\text { Geçici şokların işsizlik oranı üzerindeki etkilerinin uzun süre } \\
\text { devam ettiğini fakat söz konusu etkinin kalıcı olmadığını } \\
\text { belirlemişlerdir. }\end{array}$ \\
\hline $\begin{array}{l}\text { Koçyiğit ve vd. } \\
(2011)\end{array}$ & $\begin{array}{l}(1923-2010 \\
\text { Genel İşsizlik Oranları }\end{array}$ & $\begin{array}{l}\text { Birim Kök Testi, Yumuşak Geçişli } \\
\text { Otoregresif Modelleri ve Doğrusal } \\
\text { Olmayan } \\
\text { Etki-Tepki Fonksiyonları }\end{array}$ & $\begin{array}{l}\text { İşsizlik oranları serisinin durağan olmadığını ve iktisadi } \\
\text { dalgalanmaların işsizliğin doğal oranını etkilediğini tespit } \\
\text { etmişlerdir. }\end{array}$ \\
\hline $\begin{array}{l}\text { Bildirici ve vd. } \\
(2012)\end{array}$ & $\begin{array}{l}(2000-2010) \\
\text { Hanehalki İşücü } \\
\text { İstatistikleri }\end{array}$ & Faktör Analizi & $\begin{array}{l}\text { Histeri etkisinin olduğunu ve bu etkinin oluşumunda özellikle } \\
\text { ekonomi krizlerin etkili olduğu sonucuna ulaşmışlardır. }\end{array}$ \\
\hline $\begin{array}{l}\text { Gözgör } \\
(2012)\end{array}$ & $\begin{array}{l}(2004-2011) \\
\text { Bölgesel İşsizlik } \\
\text { Oranları }\end{array}$ & Panel Birim Kök Testleri & Histeri etkisinin varlığını tespit etmiştir. \\
\hline Arısoy (2013) & $\begin{array}{l}\text { (2005:01-2011:11) } \\
\text { Cinsiyete Göre } \\
\text { Sınıflandırılmış Işsizlik, } \\
\text { İstihdam, İşgücüne } \\
\text { Katılım Oranları }\end{array}$ & Birim Kök ve Uzun Hafıza Testleri & $\begin{array}{l}\text { Yapısal kırılmayı dikkate almayan birim kök testlerinin net } \\
\text { bir sonuç vermediği ama yapısal kırılmayı dikkate alan birim } \\
\text { kök testi ile Geweke-Porter-Hudak yöntemi sonuçlarına göre } \\
\text { şokların etkisinin kalıcı olduğunu belirlemiştir. }\end{array}$ \\
\hline $\begin{array}{l}\text { Bayat ve vd. } \\
\text { (2013) }\end{array}$ & $\begin{array}{l}(1923-2011) \\
\text { Genel İşsizlik Oranları }\end{array}$ & $\begin{array}{l}\text { Doğrusal Birim kök Testleri ve } \\
\text { Markov Rejim Değişim Modeli }\end{array}$ & $\begin{array}{l}\text { 1950'li yıllardan sonra işsizlik oranında katılıkların oluştuğu ve } \\
\text { işsizlik oranının ilk defa \%7'yi aştığı 1974'ten sonra 1996, } 1998 \\
\text { ve } 2000 \text { yılları hariç, 2012'ye kadar ki dönemde isssizlik oranının } \\
\text { aşağı doğru katılık gösterdiğini ortaya koymuşlardır. }\end{array}$ \\
\hline
\end{tabular}


Tablo 1'de yer alan çalışmalar Türkiye örneği bağlamında incelendiğinde, Türkiye'de histeri etkisinin bir çalışma dışında geçerli olduğu, genellikle yıllık verilerin kullanıldığı, ekonometrik yöntem olarak doğrusal ekonometrik yöntemlerin tercih edildiği ve özellikle birim kök testlerindeki yeni yöntemlerin uygulanmasının amaçlandığı görülmektedir. Bu çalışmada da benzer bir düşünce tarzı benimsenmiş ve Caner ve Hansen (2001) tarafından geliştirilen doğrusal olmayan birim kök testinin uygulaması ile çalışmanın literatüre olan katkısı artırılmaya çalışııımıştır.

\section{EKONOMETRIK YÖNTEM}

Birim kök testlerinde sıklıkla kullanılan ADF (Augmented Dickey-Fuller-Genişletilmiş Dickey-Fuller) ve KPSS (Kwiatkowski-Phillips-Schmidt-Shin) testlerinin doğrusal olmayan zaman serilerinde düşük güce sahip olduğu vurgulanmaktadır. Bu anlamda geliştirilen Caner ve Hansen (2001) birim kök testinde, iki rejimli otoregresif TAR (Threshold Autoregressive-Eşik Otoregresif) bir model çerçevesinde birim kök süreci incelenmektedir. Söz konusu model ise (1) no.lu denklem ile aşağıdaki şekilde tanımlanmaktadır.

$$
\Delta y_{t}=\theta_{1}^{\prime} x_{t-1} 1_{\left\{Z_{t-1}<\lambda\right\}}+\theta_{2}^{\prime} x_{t-1} 1_{\left\{Z_{t-1} \geq \lambda\right\}}+e_{t}
$$

(1) no.lu denklemde yer alan $t=1, \ldots, T$ ve $x_{t-1}=\left(y_{t-1} r_{t}^{\prime} \Delta y_{t-1}, \ldots, \Delta y_{t-k}\right)^{\prime}, 1_{\{.\}}$gösterge fonksiyonu, $e_{t}$ ise beyaz gürültü sürecine sahip hata terimi, $Z_{t}=y_{t}-y_{t-m}$ eşik (threshold) değişkeni, $m$ gecikme parametresi $(1 \leq m \leq k), k$ maksimum gecikme uzunluğu, $r_{t}$ sabit terim ve trend gibi deterministik bileşenleri içeren vektörü ifade etmektedir. Eşik değişkene ait eşik değer $\lambda$ bilinmemekte $\lambda \in\left[\lambda_{1}, \lambda_{2}\right]$ aralığında yer almakta ve söz konusu aralıkta $P\left(Z_{t} \leq \lambda_{1}\right)=\pi_{1}>0$ ve $P\left(Z_{t} \leq \lambda_{2}\right)=\pi_{2}<1$ yazılabilmektedir. Bununla birlikte, (1) no.lu modelde yer alan $\theta_{1}$ ve $\theta_{2}$ birbirinden ayrı bir biçimde incelenmiş ve (2) no.lu denklemde şu şekilde gösterilmiştir.

$$
\theta_{1}=\left[\begin{array}{l}
\rho_{1} \\
\beta_{1} \\
\alpha_{1}
\end{array}\right], \theta_{2}=\left[\begin{array}{l}
\rho_{2} \\
\beta_{2} \\
\alpha_{2}
\end{array}\right]
$$

(2) no.lu denklemde yer alan $\rho_{1}$ ve $\rho_{2}, y_{t-1}$ değişkenine ait eğim katsayılarını $\beta_{1}$ ve $\beta_{2}$ deterministik bileşenlere ait eğim katsayıları $\alpha_{1}$ ve $\alpha_{2}$ her iki rejimde yer alan $\left(\Delta y_{t-1}, \ldots, \Delta y_{t-k}\right)$ değişkenlerine ait eğim katsayılarını göstermektedir. Bu açıklamalara göre oluşturulan TAR modeli en küçük kareler yöntemi ile iki aşamada tahmin edilmektedir. Birinci aşamada, $\sigma^{2}(\lambda)$ varyansının minimize edilmesi ile eşik değer belirlenmektedir. Diğer parametreler ise $\hat{\lambda}$ 'nın nokta tahmini ile hesaplanmaktadır. Daha sonra (1) no.lu denklemde eşik etkisi $H_{0}: \theta_{1}=\theta_{2}$ şeklinde oluşturulan boş hipotez (3) no.lu denklemdeki Wald istatistiği yardımıyla hesaplanmaktadır.

$$
W_{t}=T\left(\frac{\hat{\sigma}_{0}^{2}}{\hat{\sigma}^{2}}-1\right)
$$

(3) no.lu denklemde yer alan $\hat{\sigma}^{2}$ (1) no.lu denklemde hesaplanan hata terimlerinin varyansını ve $\hat{\sigma}_{0}^{2}$ doğrusal modelin hata terimleri varyansını ifade etmektedir. Wald testinin ardından $y_{t}$ serisinin birim kök içerip içermediği $R_{2 T}, R_{1 T}$ ve $t$ istatistikleri ile araştırılmaktadır. Buna göre, (4) no.lu denklemde belirtilen çift taraflı Wald testi istatistiği $R_{2 T}$ ile $\left(H_{0}: \rho_{1}=\rho_{2}=0\right)$ hipotezi, $\left(H_{1}: \rho_{1} \neq 0\right.$ veya $\left.\rho_{2} \neq 0\right)$ hipotezine karşı sınanmaktadır.

$$
R_{2 T}=t_{1}^{2}+t_{2}^{2}
$$

(4) no.lu denklemdeki $t_{1}$ ve $t_{2}, \rho_{1}$ ve $\rho_{2}$ parametrelerine ait $t$ değerlerini göstermektedir. Bununla birlikte, Caner ve Hansen (2001), iki taraflı Wald testi istatistiğinin tek taraflı Wald testi istatistiğine göre daha zayıf olmasından dolayı (5) no.lu denklem ile belirttikleri tek taraflı Wald istatistiğini önermişlerdir. Tek taraflı Wald istatistiği yardımıyla $\left(H_{0}: \rho_{1}=\rho_{2}=0\right)$ hipotezi, $\left(H_{2}: \rho_{1}<0\right.$ veya $\left.\rho_{2}<0\right)$ hipotezine karşı sınanmaktadır.

$$
R_{1 T}=t_{1}^{2} I_{\left\{\hat{\rho}_{1}<0\right\}}+t_{2}^{2} I_{\left\{\hat{p}_{2}<0\right\}}
$$

Bu aşamada, $\left(H_{0}: \rho_{1}=\rho_{2}=0\right)$ hipotezinin red edilmesi durumunda, Caner ve Hansen (2001) $-t_{1}$ ve $-t_{2}$ istatistiklerinin kullanılabileceğini ifade etmişlerdir. Buna göre, $-t_{1}$ istatistiğinin anlamlı olması birinci rejimde serinin durağan olduğunu, $-t_{2}$ istatistiğinin anlamlı olması da ikinci rejimde serinin durağan olduğunu göstermektedir (Caner ve Hansen, 2001: 1555-1576; Madsen vd., 2008:170171ve Alp, 2008: 383-392)

\section{EKONOMETRIK ANALIZ}

\subsection{Veri Seti}

Bu çalışmada, (2005:01-2013:07) dönemi kapsayan mevsimsellik etkisinden arındırımış genel işsizlik oranı (IŞO) ve işgücüne katılma oranı (IKO) değişkenlerine ait TÜiK (Türkiye İstatistik Kurumu) veri tabanından elde edilen seriler kullanılmış ve söz konusu serilerin çalışmanın kapsadığı dönem içerisindeki gelişimleri Şekil 1'de gösterilmiştir. 


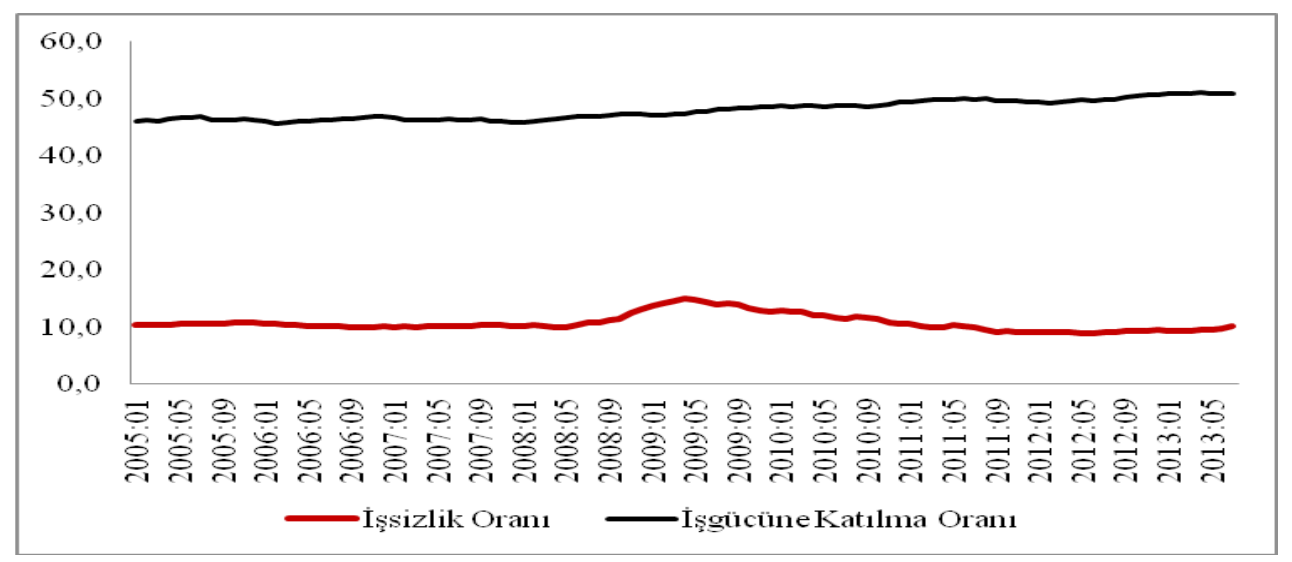

Şekil 1: (2005:01-2013:07) Dönemi İşsizlik Oranları ve İşü̈cüne Katılma Oranları

(Kaynak: http://www.tuik.gov.tr)

Şekil 1'den görüleceği üzere, çalışmanın kapsadığı dönem içerisinde işsizlik oranı ve işgücüne katılm oranı serilerinin gelişimi incelendiğinde, işsizlik oranlarının 2008'de yaşanan küresel ekonomik kriz sonrasında yükseldiği fakat daha sonra azalma sürecine girdiği, işgücüne katılma oranı serisinin ise dönemin başından itibaren yükselme eğilimine girdiği görülmektedir. Bu noktada, Türkiye'nin işsizlik oranları ile işgücüne katılma oranları, Şekil 2 ve Şekil 3' de gösterildiği üzere Avrupa, OECD ve G7 ülkeleri ile karşılaştırıldığında; küresel ekonomik kriz sonrasında, Türkiye'de işsizlik oranları ile söz konusu ülke gruplarına ait ortalama işsizlik oranları farkının azaldığı ve 2012 yılı itibariyle Avrupa Ülkeleri ortalamasının altında kaldığı gözlen- mektedir. Aynı karşılaştırma işgücüne katılma oranları kullanılarak yapıldığında, Türkiye'de işgücüne katılma oranlarının, karşılaştırma yapılan ülke gruplarına ait ortalama değerlerin yaklaşık yüzde 20 oranında altında kaldığı tespit edilmektedir. Bu anlamda, işgücüne katılma oranları arasındaki yüzde 20 düzeylerindeki bu fark giderildiğinde, Türkiye'de (2000-2012) döneminde işsizlik oranlarında yaklaşık yüzde dört seviyesinde bir artış meydana gelmektedir. Bu sonuç, Türkiye'de işsizliğin önemli bir problem olduğunu ve sadece mevcut işsizlik oranları kullanılarak yapılacak karşılaştırmalarda, ülkelerin işgücüne katılma oranları arasındaki farkların da göz önüne alınmasını ortaya koymaktadır.

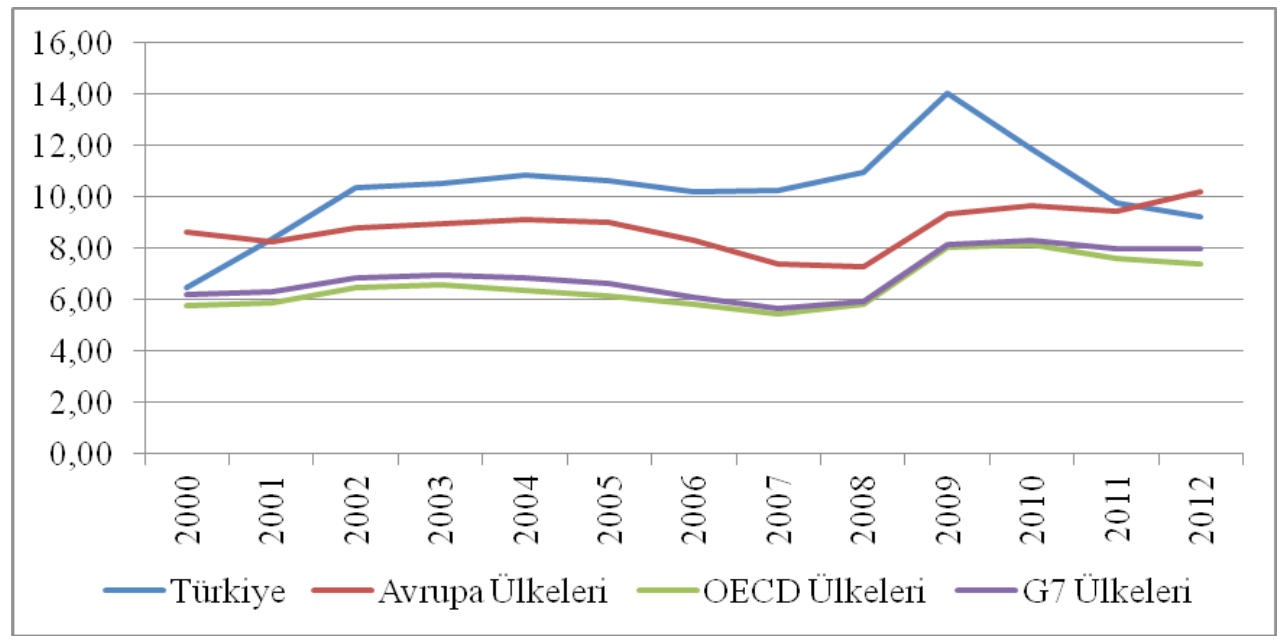

Şekil 2: (2002-2012) Dönemi Türkiye ve Seçilmiş Ülke Gruplarına Ait İşsizlik Oranları

(Kaynak: http://www.oecd.org/statistics/) 


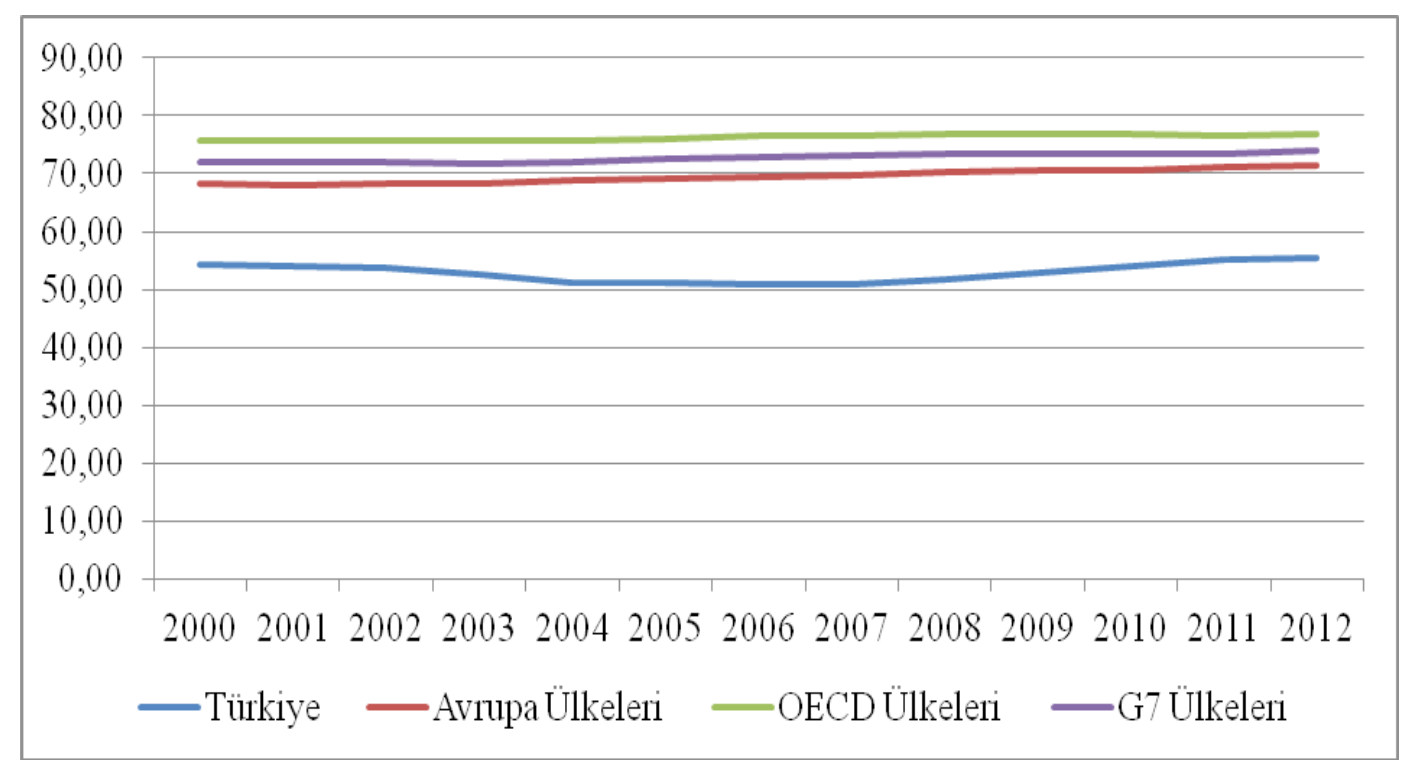

Şekil 3: (2002-2012) Dönemi Türkiye ve Seçilmiş Ülke Gruplarına Ait İşgücüne Katılma Oranları

(Kaynak: http://www.oecd.org/statistics/)

\subsection{Uygulama Sonuçları}

TAR birim kök testi uygulamasından önce çalışmada kullanılan serilerin birim kök içerip içermedikleri ilk olarak doğrusal ve serilerdeki yapısal kırılmayı dikkate almayan birim kök testlerinden ADF (Augmented Dickey-Fuller), PP (Phillips-Perron) ve KPSS (Kwiatkowski, Phillips, Schmidt ve Shin) birim kök testleri yardımıyla incelenmiştir ve elde edilen sonuçlar Tablo 2'de gösterilmiştir.

Tablo 2: Birim Kök Testi Sonuçları-1

\begin{tabular}{|c|c|c|c|c|c|c|}
\hline \multirow{2}{*}{ Seriler } & \multicolumn{2}{|c|}{ ADF } & \multicolumn{2}{c|}{ PP } & \multicolumn{2}{c|}{ KPSS } \\
\cline { 2 - 7 } & $\mathrm{a}$ & $\mathrm{b}$ & $\mathrm{a}$ & $\mathrm{b}$ & $\mathrm{a}$ & $\mathrm{b}$ \\
\hline IŞO & $-1.7900(6)$ & $-1.8144(6)$ & $-1.5444(7)$ & $-1.6064(7)$ & $0.2201^{(1)}(8)$ & $0.2009(8)$ \\
\hline IKO & $-0.1313(1)$ & $-2.5279(1)$ & $-0.0416(1)$ & $-2.1746(1)$ & $1.1761(8)$ & $0.1966(8)$ \\
\hline
\end{tabular}

(Not: 1) Parantez içerisindeki değerler, ADF testi için gecikme uzunluklarını, PP ve KPSS testi için ise uygun band genişliklerini göstermektedir. 2) ADF testi için ise uygun gecikme uzunluğunun belirlenmesinde Schwarz Bilgi kriteri, PP ve KPSS testlerinde uygun band genişliğinin belirlenmesinde ise Newey-West Bandwidth kriteri kullanılmıştır. 3) a: Sabitli Modeli, b: Sabitli ve Trendli Modeli, (1) ifadesi ilgili serinin yüzde 5 önem düzeyinde birim kök içermediğini ifade etmektedir. )

Tablo 2'de yer alan sonuçlar incelendiğinde yapısal kırılma olması durumunda birim kök vardır özellikle ADF ve PP testi sonuçlarının tamamında hipotezini kabul etme eğilimlerinin yüksek olması çalışmada kullanılan serilerin tümünün birim kök nedeniyle (Perron, 1989, 1990), serideki olası yapısal içerdiği, KPSS testi sonuçlarına göre ise sabitli mod- kırılmaları dikkate alan Lee-Strazicich (2003) birim elde (işO) serisi dışındaki diğer durumlarda söz ko- kök testinin uygulanmasına karar verilmiş ve elde edinusu serilerin birim kök içerdiği tespit edilmiştir. Fakat yapısal kırılmayı dikkate almayan bu testlerin, seride

len sonuçlar Tablo 3'de sunulmuştur.

Tablo 3: Birim Kök Testi Sonuçları-2

\begin{tabular}{|c|c|c|c|c|c|c|}
\hline Seriler & Model A (t-ist.) & \multicolumn{2}{|c|}{ Kırılma Tarihleri } & Model C (t-ist.) & \multicolumn{2}{c|}{ Kırılma Tarihleri } \\
\hline IŞO & $-2.9764(8)$ & $2009: 11$ & $2010: 02$ & $-5.8562^{(1)}(8)$ & $2008: 09$ & $2010: 08$ \\
\hline IKO & $-3.0506(5)$ & $2007: 01$ & $2009: 06$ & $-6.2400^{(1)}(6)$ & $2007: 09$ & $2009: 11$ \\
\hline
\end{tabular}

( Not: 1) Parantez içerisindeki değerler uygun gecikme uzunluklarını göstermektedir. 2) Model A: Sabitli, Model C: Sabitli ve Trendli modeli ifade etmektedir. 3) Model A için yüzde 5 önem düzeyinde kritik değer -3.842; Model C için farklı kırılma zamanları için yüzde 5 önem düzeyindeki kritik değerler: $-5.59,-5.74,-5.67,-5.71,-5.65,-5.73$ olarak ifade edilmektedir. Bknz. Lee- Strazicich, 2003: 1084. 4) (t-ist.) " $t$ " istatistik değerini ifade etmektedir. 5) (1) ifadesi ilgili serinin yüzde 5 önem düzeyinde birim kök içermediğini ifade etmektedir.) 
Lee-Strazicich (2003) birim kök testi sonuçlarına göre Model A'ya göre çalışmada kullanılan serilerin tümünün birim kök içerdiği buna karşılık Model C'ye göre ise birim kök içermediği belirlenmiştir. Bu sonuçlar, serilerdeki yapısal kırılmalar dikkate alındığında serilerin durağan olmadığını gösteren boş hipotezin kabul edilmeme eğiliminin yükseldiğini göstermektedir. Her ne kadar serilerdeki yapısal kırılmaları dikkate alan birim kök testlerinin üstün yönleri bulunsa da, gerek yapısal kırılmayı dikkate almayan gerekse yapısal kırılmayı dikkate alan birim kök testleri ilgili zaman serisinin doğrusal bir yapıya sahip olduğunu kabul etmektedir. Buna karşılık Caner ve Hansen (2001)'de belirtikleri üzere, eğer herhangi bir zaman serisinin doğrusal olmayan bir sürece sahip olduğu tespit edilmişse, doğrusal olmayan birim kök testi daha güçlü sonuçlar ortaya koymaktadır. Bu nedenle Caner ve Hansen birim kök testi gerçekleştirilmiş ve bunun için öncelikle çalışmada kullanılan serilerin doğrusal olup olmadığını tespit edilmiş ve elde edilen sonuçlar Tablo 4'de sunulmuştur.

Tablo 4: Wald Testi Sonuçları

\begin{tabular}{|c|c|c|c|c|c|c|}
\hline Seriler & $a$ & $\begin{array}{c}\text { Gecikme } \\
\text { Uzunluğu }\end{array}$ & $\begin{array}{c}\text { Olasılık } \\
\text { Değeri }\end{array}$ & $\mathrm{b}$ & $\begin{array}{c}\text { Gecikme } \\
\text { Uzunluğu }\end{array}$ & $\begin{array}{c}\text { Olasılık } \\
\text { Değeri }\end{array}$ \\
\hline işO & 42.1000 & 2 & 0.0010 & 44.1000 & 5 & 0.0047 \\
\hline IKO & 23.3000 & 1 & 0.1780 & 22.3000 & 2 & 0.8040 \\
\hline
\end{tabular}

( Not: 1) a: Sabitli, b: Sabitli ve Trendli modeli ifade etmektedir. Wald testi gerçekleştirilirken maksimum gecikme uzunluğu çalışmadaki gözlem sayısı dikkate alınarak 8 (sekiz) olarak alınmışır. )

Tablo 4'deki sonuçlara göre, yüzde 5 önem düzeyinde (IŞO) serisinin doğrusal olmayan (IKO) serisinin ise doğrusal bir yapı taşıdığı belirlenmiştir. Bu sonuçlara göre, (IŞO) serisi için doğrusal olmayan birim kök testi gerçekleştirilmesine karar verilmiştir ve tespit edilen sonuçlar Tablo 5'de sunulmuştur.

Tablo 5: Tek Taraflı ve Parçalı Birim Kök Testi Sonuçları

\begin{tabular}{|c|c|c|c|c|c|c|c|c|}
\hline \multirow{2}{*}{ Seriler } & \multicolumn{2}{|c|}{$R_{1 T}$ İst. Değeri } & \multicolumn{2}{c|}{$R_{2 T}$ ist. Değeri } & \multicolumn{2}{c|}{$t_{1}^{2}$ ìst. Değeri } & \multicolumn{2}{c|}{$t_{2}^{2}$ İst. Değeri } \\
\cline { 2 - 8 } & $\mathrm{a}$ & $\mathrm{b}$ & $\mathrm{a}$ & $\mathrm{b}$ & $\mathrm{a}$ & $\mathrm{b}$ & $\mathrm{a}$ & $\mathrm{b}$ \\
\hline \multirow{2}{*}{ işo } & 11.7000 & 17.9000 & 11.7000 & 17.9000 & 0.4840 & 1.7400 & 3.3800 & 3.8600 \\
& $(0.0827)$ & $(0.0960)$ & $(0.1070)$ & $(0.1030)$ & $(0.6330)$ & $(0.0526)$ & $(0.0260)$ & $(0.0371)$ \\
\hline
\end{tabular}

( Not: 1) a: Sabitli, b: Sabitli ve Trendli modeli ifade etmektedir. )

Tablo 5'deki sonuçlar incelendiğinde, yüzde 5 belirlenen eşik değerlerin üstünde yer alan ikinci önem düzeyinde göre işo serisinin $t_{2}^{2}$ istatistiğine göre sabitli, sabitli ve trendli modelde, Tablo 6'da

rejimde birim kök içermediği tespit edilmiştir. Belirlenen rejimlere ait gözlem değerleri ise Şekil 4'de gösterilmiştir.

Tablo 6: TAR Modeli Sonuçları

\begin{tabular}{|c|c|c|c|c|c|c|c|c|}
\hline \multirow{4}{*}{ Değişkenler } & \multicolumn{4}{|c|}{$\begin{array}{c}\text { IŞO Serisi için } \\
\text { TAR Modeli Sonuçları }\end{array}$} & \multicolumn{4}{|c|}{$\begin{array}{c}\text { IŞO Serisi için } \\
\text { TAR Modeli Sonuçları }\end{array}$} \\
\hline & \multicolumn{2}{|c|}{ Rejim 1 (n:20) } & \multicolumn{2}{|c|}{ Rejim 2 (n:74) } & \multicolumn{2}{|c|}{ Rejim 1 (n: 15) } & \multicolumn{2}{|c|}{ Rejim 2 (n:79) } \\
\hline & \multicolumn{2}{|c|}{$Z_{t-1}<-0.3040$} & \multicolumn{2}{|c|}{$Z_{t-1} \geq-0.3040$} & \multicolumn{2}{|c|}{$Z_{t-1}<-0.8500$} & \multicolumn{2}{|c|}{$Z_{t-1} \geq-0.8500$} \\
\hline & Katsayı & $\begin{array}{l}\text { Standart } \\
\text { Hata }\end{array}$ & Katsayı & $\begin{array}{c}\text { Standart } \\
\text { Hata }\end{array}$ & Katsayı & $\begin{array}{c}\text { Standart } \\
\text { Hata }\end{array}$ & Katsayı & $\begin{array}{l}\text { Standart } \\
\text { Hata }\end{array}$ \\
\hline Sabit Terim & 0.4680 & 0.0252 & 0.6110 & 0.1890 & 20.1000 & 11.7000 & 0.7810 & 0.2080 \\
\hline Trend & - & - & - & - & -0.1450 & 0.0909 & -0.0000 & 0.0006 \\
\hline$Y_{t-1}$ & -0.0175 & 0.0362 & -0.0610 & 0.0180 & -0.8720 & 0.5020 & -0.0726 & 0.0188 \\
\hline$\Delta Y_{t-1}$ & 0.9580 & 0.3860 & 0.6160 & 0.1210 & 1.0700 & 0.5320 & 0.5870 & 0.1070 \\
\hline$\Delta Y_{t-2}$ & 0.4810 & 0.2970 & 0.5950 & 0.1220 & 1.8600 & 0.6830 & 0.4400 & 0.1210 \\
\hline$\Delta Y_{t-3}$ & -0.8560 & 0.1980 & -0.4900 & 0.1160 & 1.5500 & 0.7400 & -0.4880 & 0.1060 \\
\hline$\Delta Y_{t-4}$ & 0.0941 & 0.2010 & 0.4130 & 0.1230 & 0.4290 & 0.4730 & 0.5520 & 0.1170 \\
\hline$\Delta Y_{t-5}$ & 0.2630 & 0.2210 & 0.3340 & 0.1240 & 1.2900 & 0.4770 & 0.4000 & 0.1340 \\
\hline$\Delta Y_{t-6}$ & -0.2710 & 0.2390 & -0.4800 & 0.1070 & -0.5860 & 0.2960 & -0.5010 & 0.1110 \\
\hline$\Delta Y_{t-7}$ & 0.4400 & 0.1790 & -0.0585 & 0.1280 & -0.6260 & 0.5070 & 0.0148 & 0.1100 \\
\hline$\Delta Y_{t-8}$ & 0.0252 & 0.2020 & 0.2320 & 0.1130 & 0.1230 & 0.2880 & 0.3070 & 0.1100 \\
\hline
\end{tabular}




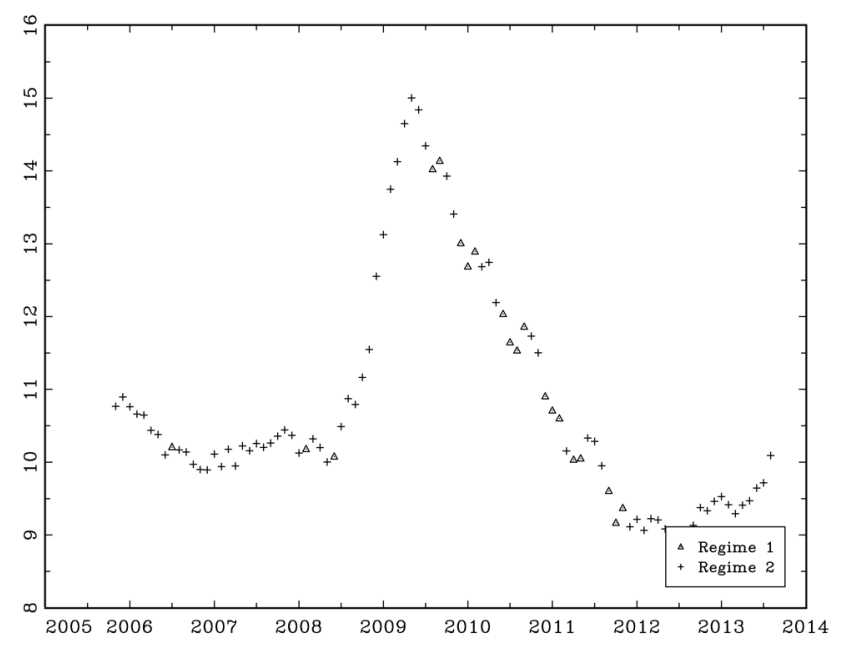

Şekil 4: Rejim Dönemleri (Sabitli Model) ( Not: Regime 1: Birinci rejim, Regime 2: İkinci rejim)

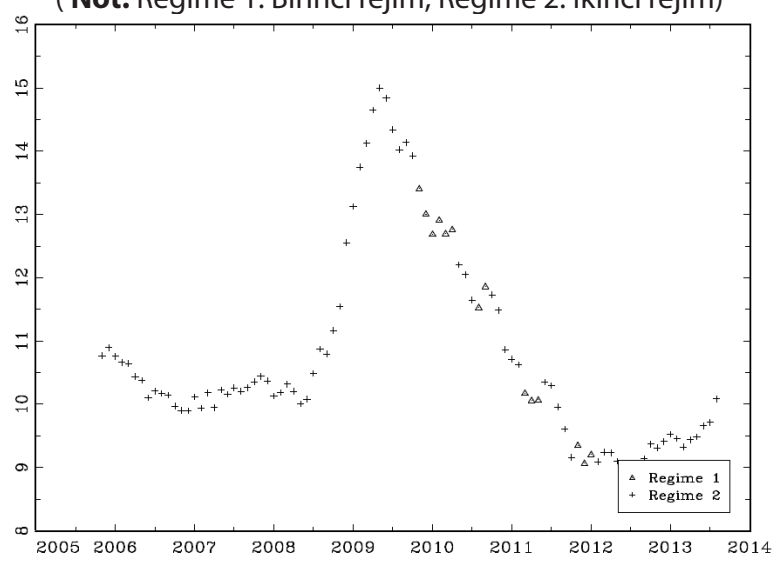

Şekil 5: Rejim Dönemleri (Sabitli ve Trendli Model)

(Not: Regime 1: Birinci rejim, Regime 2: İkinci rejim)

\section{SONUÇ}

Bu çalışmada, işsizlik oranlarında histeri etkisinin varlığı Türkiye ekonomisi bağlamında incelenmiştir. Çalışmada, histeri etkisinin varlığının araştırılması noktasında genel işsizlik oranı ve işgücüne katılma oranı serileri kullanılmış ve doğrusal birim kök testleri ile birlikte doğrusal olmayan birim kök testi uygulamasına da yer verilerek çalışmanın literatüre olan katkısının artırılması amaçlanmıştır.

Bu bağlamda, serilerdeki yapısal kırılmayı dikkate almayan birim kök testi sonuçlarına göre çalışmada kullanılan serilerin, bir test dışında birim kök içerdiği, serilerdeki yapısal kırılmayı dikkate alan birim kök test sonuçlarına göre ise söz konusu serilerin tamamının birim kök içermediği belirlenmiştir. Doğrusal olmayan birim kök testlerine göre daha etkili sonuçlar vermesi nedeniyle tercih edilen Caner ve Hansen (2001) birim kök testi uygulaması sonuçlarına göre ise doğrusal olmayan bir yapı taşıdığı belirlenen genel işsizlik oranı serisinin ikinci rejimde birim kök içermediği, diğer bir deyişle herhangi bir şok karşısında değişen işsizlik oranlarının tekrar şoktan önceki denge düzeyine geldiği tespit edilmiştir. Bu sonuç, Türkiye'de işgücü piyasasının etkin çalışmadığını ve bu nedenle de işsizlik oranlarında histeri etkisinin oluşmaması için işsizlik oranlarını azaltıcı önlemlerin alınması gerekliliğini göstermektedir. Bununla birlikte çalışmada, doğrusal bir yapı taşıyan işgücüne katılma oranı serisinin yapısal kırılmayı dikkate alan birim kök testi sonuçlarına göre birim kök içermemesi nedeniyle Türkiye'de işsizlik oranlarında histeri etkisinin incelenmesinde genel işsizlik oranlarının kullanılabileceği sonucu da elde edilmiştir. 


\section{SON NOTLAR}

${ }^{1}$ Ekonomideki bir şoktan sonra işsizlik oranlarının eski seviyesine dönmemesi, ekonometrik açıdan işsizlik serisinin durağan olmayan bir süreç tarafından türetilmesi şeklinde tanımlanmaktadır (Güloğlu ve İspir, 2011: 205). Diğer bir deyişle, işsizlik oranları serisinin birim kök içermesi, işşizlik oranlarında histeri etkisinin varlığını göstermektedir. Bu nedenle de, işsizlik oranlarında histeri etkisinin araştırılmasını konu alan çalışmalarda birim kök testleri tercih edilmektedir.

${ }^{2}$ Aslında çalışmada doğrusal birim kök testleri de kullanılmakla birlikte söz konusu birim kök testleri ile ilgili olarak diğer çalışmalarda yeterli ölçüde bilgi verilmesi nedeniyle bu çalışmada sadece doğrusal olmayan birim kök testinin açıklanması tercih edilmiştir.

\section{KAYNAKLAR}

Andersen, T.M. (2010) "Unemployment Persistence" CESifo Forum, 11(1):23-28.

Arısoy, İ. (2013) “Türkiye'de İşgücü Piyasasına Etki Eden Şokların Kalıcılığının Analizi” TISK Akademi, 8(15): 22-41.

Alp, E.A. (2008) “Türkiye'de Sanayi Üretim Endeksinin TAR Modeli ile Analizi ve Birim Kök Sınaması" 1. Mühendislik ve Teknoloji Sempozyumu, Ankara.

Blanchard, O.J. ve Summers, L.H. (1986)

"Hysteresis and the European Unemployment Problem" Fischer, S. (ed.) NBER Macroeconomics Annual, Cambridge, MIT Press.

Blanchard, O.J. ve Summers, L.H.(1987) "Hysteresis in Unemployment" European Economic Review, 31:288-295.

Barışık, S. ve Çevik, E.İ. (2008) "Yapısal Kırılma Testleri ile Türkiye’de İşsizlik Histerisinin Analizi: 19232006 Dönemi" KMU Sosyal ve Ekonomik Araştırmalar Dergisi, 10(14): 109-134.

Barışık, S. ve Çevik, E.İ. (2008) “Türkiye’de İşsizlik Histerisinin Yapısal Kırılma ve Güçlü Hafıza Modellemesi ile Sektörel Analizi” TÍSK Akademi, 3(6):67-87.

Barro, R. (1988) "The Persistence of Unemployment" The American Economic Review, 78(2): 32-37.

Bayat, T., Kayhan, S. ve Koçyiğit, A. (2013) "Türkiye'de İşsizliğin Asimetrik Davranışının Rejim Değişim Modeliyle İncelenmesi” Business and Economics Research Journal, 4(2): 79-90.

Bildirici, M., Ersin, Ö. Ö., Türkmen, C., ve Yalçınkaya, Y. (2012) "The Persistence Effect of Unemployment in Turkey: An Analysis of the 1980-2010 Period" Journal of Business Economics \& Finance, 1(3): 22-32.

Burda, M. (1988) "Is There a Capital Shortage in Europe? Weltwirtschaftliches Archiv, 124: 38-57.

Camero, M. ve Tamarit, C. (2004) "Hysteresis vs. Natural Rate Of Unemployment: New Evidence For OECD Countries" Economics Letters, 84: 413-417.
Camero, M., Carrion-i-Silvestre, J. L. ve Tamarit, C. (2008) "Unemployment Hysteresis in Transition Countries: Evidence Using Stationary Panel Tests with Breaks" Review of Development Economics, 12(3):620-635.

Caner, M. ve Hansen, B.E. (2001) "Threshold Autoregression with a Unit Root" Econometrica, 69(6):1555-1596.

Chang, T., Lee, K-C., Nieh, C-C. ve Wei, C-C. (2005) "An Empirical Note on Testing Hysteresis in Unemployment for Ten European Countries: Panel SURADF Approach" Applied Economic Letters, 12: 881886.

Chang, T. ve Lee, C-H. (2011) "Hysteresis in Unemployment for G-7 Countries: Threshold Unit Root Test" Romanian Journal of Economic Forecasting, 4: 5-14.

Cross, R. (1987) "Hysteresis and Instability in the Natural Rate of Unemployment" Scandinavian Journal of Economics, 89(1): 71-89.

Cuestas, J.C., Gil-Alana, L.A. ve Staehr, K. (2011) "A Further Investigation of Unemployment Persistence in European Transition Economies" Journal of Comparative Economics, 39: 514-532.

Fosten, J. ve Ghoshray, A. (2011) "Dynamic Persistence in the Unemployment Rate of OECD Countries” Economic Modelling, 28: 948-954.

Friedman, M. (1968) "The Role of Monetary Policy" The American Economic Review, 58(1): 1-17.

Gil-Alana, A.L. (2002) "Modelling the Persistence of Unemployment in Canada" International Review of Applied Economics, 16(4): 465-477.

Gözgör, G. (2012) "Hysteresis in Regional Unemployment Rates in Turkey" International Journal of Economics and Finance, 4(9): 175-181.

Gustavsson, M. ve Österholm, P. (2006) "The Informational Value of Unemployment Statistics: A Note on the Time Series Properties of Participation Rates" Economics Letters, 92: 428-433. 
Gustavsson, M. ve Österholm, P. (2007) "Does Unemployment Hysteresis Equal Employment Hysteresis" The Economic Record, 83(261): 159-173.

Güloğlu, B. ve İspir, M.S. (2011) "Doğal İşsizlik Oranı mı? İşsizlik Histerisi mi? Türkiye için Sektörel Panel Birim Kök Sınaması Analizi” Ege Akademik Bakı̧̧, 11(2): 205-215.

Hargraves, H.S.P (1980) "Choosing the Wrong Natural Rate: Accelerating Inflation or Deceleration Employment and Growth" Economic Journal, 90:611-620.

Jaeger A. ve Parkinson, M. (1990) "Testing for Hysteresis in Unemployment an Unobserved Components Approach" Empirical Economics, 15:185-198.

Koçyiğit, A., Bayat, T. ve Tüfekçi, A. (2011) "Türkiye'de İşsizlik Histerisi ve STAR Modelleri Uygulaması" Marmara Üniversitesi I.I. B. B.F. Dergisi, 31(2): 45-60.

Küçükkale, Y. (2001) "Doğal İşssizlik Oranındaki Keynesyen İsteri Üzerine Klasik Bir İnceleme: Kalman Filtre Tahmin Tekniği ile Türkiye Örneği 1950-1995”, V. Ulusal Ekonometri ve İstatistik Sempozyumu, Adana.

Layard, R., Nickell, S. ve Jackman, R. (1991) Unemployment, Macroeconomic Performance and the Labour Market, Oxford, Oxford University Press.

Lee, J. ve Strazicich, M. C. (2003) “Minimum Lagrange Multiplier Unit Root Test with Structural Breaks" The Review of Economics and Statistics, 85(4):1082-1089.

Lee, C-F. (2010) “Testing for Unemployment Hysteresis in Nonlinear Heterogeneous Panels: International Evidence" Economic Modelling, 27:1097-1102.

Lindbeck, A. ve Snower, D. J. (1988) "Cooperation, Harassment, and Involuntary Unemployment: An Insider-Outsider Approach" The American Economic Review, 78(1): 167-188.

Lindbeck, A. ve Snower, D. (2001) "Insiders versus Outsiders” Journal of Economic Perspectives, 15(1):165-188.

Mikhail, O., Eberwein, C. J. ve Handa, J. (2006) "Estimating Persistence in Canadian Unemployment: Evidence from a Bayesian ARFIMA" Applied Economics, 38: 1809-1819.

Madsen, J., Mishra V. ve Smyth, R. (2008) "Are Labour Force Participation Rates Non-Stationary? Evidence from 130 Years for G7 Countries" Australian Economic Papers, 47: 166-189.

Murphy, K. M. ve Topel, R. (1997) "Unemployment and Nonemployment" The American Economic Review, 87(2): 295-300.

Neudorfer, P., Pichelmann, K. ve Wagner, M. (1990) "Hysteresis, Nairu and Long Term Unemployment in Austria" Empirical Economics, 15: 217-229.
Papell, D. H., Murray, C. J. ve Ghiblawi, H. (2000) "The Structure of Unemployment" The Review of Economics and Statistics, 82(2):309-315.

Perron, P. (1989) "The Great Crash, the Oil Price Shock, and The Unit Root Hypothesis" Econometrica, 57(6): 1361-1401.

Perron, P. (1990) "Testing for a Unit Root in a Time Series with a Changing Mean" Journal of Business\&Economic Statistics, 8(2): 153-162.

Phelps, E. (1967) "Philips Curves, Expectations of Inflation and Optimal Unemployment Over Time" Economica, 34(135): 254-281.

Phelps, E. (1968) "Money, Wage Dynamics and Labor-Market Equilibrium” Journal of Political Economy, 76(4): 678-711.

Phelps, E.S. (1972) Inflation Policy and Unemployment Theory, London, Macmillan.

Phelps, E.S. (1994) Structural Slumps: The Modern Equilibrium Theory of Unemployment, Interest, and Assets, Cambridge, Harvard University Press.

Pissarides, C. (1992) "Loss of Skill During Unemployment and the Persistence of Employment Shocks" Quarterly Journal of Economics, 107: 1371-1391.

Røed, K. (1996) "Unemployment HysteresisMacro Evidence from 16 OECD Countries” Empirical Economics, 21: 589-600.

Romero-Ávila, D. ve Usabiaga, C. (2008) "On the Persistence of Spanish Unemployment Rates” Empirical Economics, 35: 77-99.

Sneessens, H. (1983) "A Macroeconomic Rationing Model of the Belgian Economy" European Economic Review, 20: 193-215.

Sneessens, H.R. ve Dreze, J. (1986) "A Discussion of Belgian Unemployment Combining Traditional Concepts and Disequilibrium Econometrics" Economica, 53: 89-119.

Yilanc1, V. (2008) "Are Unemployment Rates Nonstationary or Nonlinear? Evidence from 19 OECD Countries" Economics Bulletin, 3(47): 1-5.

Yılancı, V. (2009) "Yapısal Kırılmalar Altında Türkiye için İşsizlik Histerisinin Sınanması” Doğuş Üniversitesi Dergisi, 10(2): 324-335. 